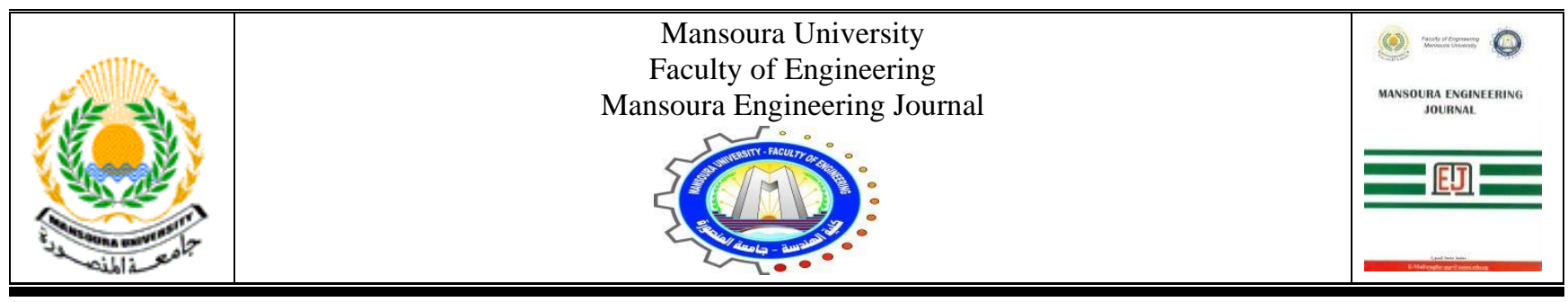

\title{
Effect of increasing organic loading rate on the performance of conventional and modified sequencing batch reactors
}

\author{
Hossam A. Abdelaziz, Moharram Fouad and Mohamed Mossad
}

\author{
KEYWORDS: \\ Conventional SBR \\ Biofilm \\ Organic loading rate \\ SVI \\ Bio-sludge \\ Municipal wastewater
}

\begin{abstract}
A modified sequencing batch reactor (MSBR) was developed by installing six fiber vertical plates of specific surface area of $180 \mathrm{~cm}^{2} / \mathrm{L}$ in conventional sequencing batch reactor (SBR), which designed for supporting the biofilm formation and increasing the system efficiency. In this study, the effect of increasing the organic loading rate of $281.25 \mathrm{~g} \mathrm{COD} / \mathrm{m}^{3}$. d by $33 \%, 67 \%$, and $100 \%$ on the performance of SBR and MSBR was investigated. The effluent $\mathrm{BOD}_{5}$, COD and TSS of the MSBR at high organic loading rate was 20, 32 and $27 \mathrm{mg} / \mathrm{L}$, respectively, while for conventional $S B R$ was 34,58 and $45 \mathrm{mg} / \mathrm{L}$, respectively. The total bio-sludge of MSBR was more than that of conventional SBR by about $30 \%$ resulting in a reduction of the $F / M$ value. The sludge volume index (SVI) in MSBR was lower than that of conventional SBR by about $33 \%$. MSBR system was able to treat municipal wastewater with high performance.
\end{abstract}

\section{INTRODUCTION}

$\mathrm{S}$ BR consists of a sequencing steps including filling, reaction, settling, decanting and idle [1]. SBR still suffer from some problems, such as excess sludge and a high SVI [2]. The sequencing batch biofilm reactor (SBBR) has an ability to combine the advantages of both biofilm reactor and SBR. Many researches have been performed by developing SBR to provide a high surface area for biofilm growth. SBBRs have already been used in the treatment of domestic wastewater [3 - 6]. A high surface area of carriers can provide more sites for microorganisms to absorb and grow [7]. The attached biofilm can be more

Received: (1 September, 2020) - Revised: (26 September, 2020) Accepted: (6 October, 2020)

Corresponding Author: Hossam ElDin Ahmed Abdelaziz Mohamed, Demonstrator at Delta Higher Institute for Engineering and Technology. (Email: eng.hossamahmed8@gmail.com).

Prof. Dr. Moharram Fouad, Head of Public Works Eng. Department, Faculty of Engineering, Mansoura University. (E-mail: mf12317@gmail.com).

Assoc. Prof. Dr. Mohamed Mossad, Associate Professor, Public Works Department, Faculty of Engineering - Mansoura University. (E-mail: maahm@mans.edu.eg). resistant to shock organic loads [8]. Aziz et al. [9] reported that the removal efficiency of the SBR with fibers that served as biofilm carriers achieved a higher performance as compared with the SBR without fibers. Sirianuntapiboon et. al. [10] reported that, the removal efficiencies of $\mathrm{COD}$ and $\mathrm{BOD}_{5}$ for the sequencing batch biofilm reactor (SBBR) system were 89.3 and $83 \%$, respectively, and for the conventional SBR system were 87.0 and $79.9 \%$, respectively, under organic loading $1340 \mathrm{~g} \mathrm{BOD}_{5} / \mathrm{m}^{3} \mathrm{~d}$. Al-Sarawy et al. [11] investigated SBBR for treatment of slaughterhouse wastewater and reported that, the SBBR was an efficient system. In this research, system of attached biofilm was utilized in SBR by adding fixed plates in the SBR to enhance the removal efficiency and improve sludge properties. The main objective of this research is to assess the removal efficiencies of $\mathrm{BOD}_{5}$, COD, and TSS under different organic loading rates for SBR and MSBR for treating municipal wastewater.

\section{Methodology}

\subsection{Reactors setup}

One cylindrical feeding tank of total volume of $187 \mathrm{~L}$ (diameter of $63 \mathrm{~cm}$ and height of $60 \mathrm{~cm}$ ) and two systems of SBR were used, the conventional SBR and modified SBR (MSBR). Each reactor had dimensions of $70 \mathrm{~cm}$ length, $50 \mathrm{~cm}$ 
width and $50 \mathrm{~cm}$ high and working volume of $168 \mathrm{~L}$. The aeration system was proceeded with the aid of one blower (model EL $55 \mathrm{AV}$ and made in Egypt) that supplied a flow rate of air of $100 \mathrm{~L} / \mathrm{min}$ through a diffuser located at a height of $5 \mathrm{~cm}$ from the reactor bottom. The effluent was discharged from the four ports that were located at different heights to keep the volumetric exchange rate (VER) at $37.5,50,62.5$ and $75 \%$. The height of the four ports (center to center distance) from the bottom of the system were distributed at different interval along the effective height of the reactor as the following $12 \mathrm{~cm}, 18 \mathrm{~cm}, 24 \mathrm{~cm}$ and $30 \mathrm{~cm}$. Feeding, withdrawing and sludge waste were accomplished by gravity. Schematic of the conventional and modified SBRs were shown in Fig.1. The characteristics of vertical plates that were installed on the stainless-steel frame and were not easily affected by air flow. The plates were made from fiber material because of high resistance, nominal spacing between plates was $10 \mathrm{~cm}$. Properties of fixed plates were shown in Table 1 .

Table 1.

\begin{tabular}{|c|c|}
\hline \multicolumn{2}{|c|}{ Properties of fixed plates } \\
\hline Properties & Value \\
\hline Dimensions of each plate & $\begin{array}{l}40 \mathrm{~cm} \text { in width, } 60 \mathrm{~cm} \text { in length } \\
\text { and } 1 \mathrm{~mm} \text { in thickness }\end{array}$ \\
\hline Weight of each plate & $15 \mathrm{gm}$ \\
\hline Number of plates in MSBR & 6 \\
\hline Surface area of biofilm for each plate & $0.48 \mathrm{~m}^{2}$ \\
\hline
\end{tabular}

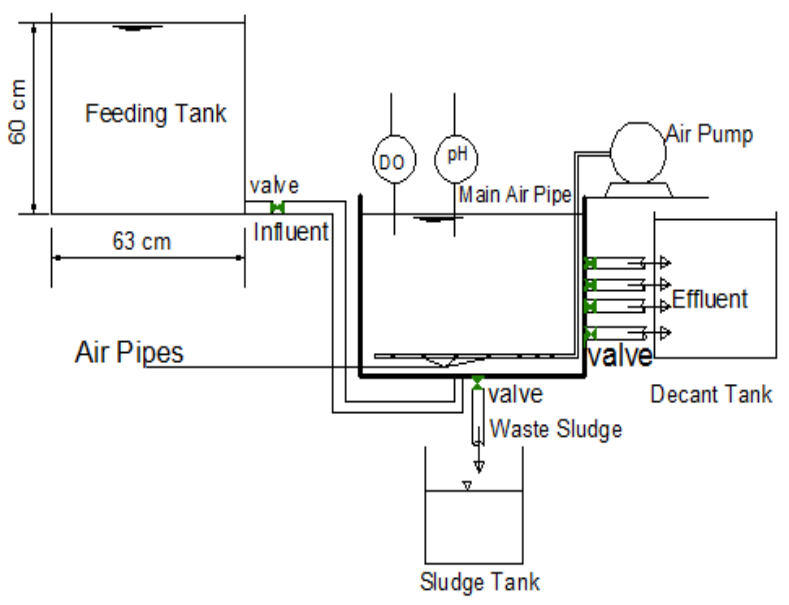

(a)SBR

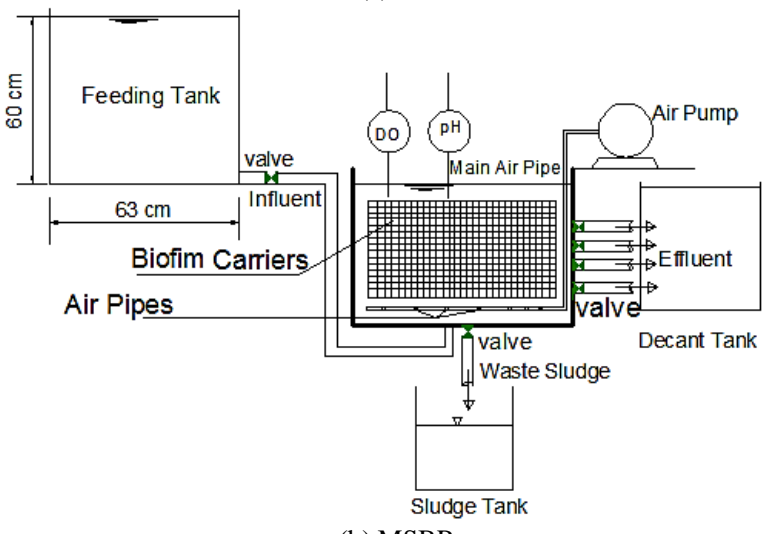

(b) MSBR

Fig.1. Schematic diagrams of (a) SBR and (b) MSBR

\subsection{Characteristics of influent wastewater}

Influent wastewater was taken from the exit of the grit removal tank from wastewater treatment plant (W.W.T.P) of
Bilqas that located in the El Dakahila governorate in Egypt and working by activated sludge processes "ASP" with a capacity of $20000 \mathrm{~m}^{3} / \mathrm{day}$. The influent wastewater was characterized by carrying out $\mathrm{COD}, \mathrm{BOD}_{5}, \mathrm{TSS}, \mathrm{pH}, \mathrm{DO}$ and temperature as shown in Table 2.

Table 2 .

\begin{tabular}{c||c||c}
\multicolumn{2}{c}{ Characteristics of influent wastewater } \\
Parameters & Unit & Average values \\
\hline COD & $\mathrm{mg} / \mathrm{L}$ & $250 \pm 24$ \\
\hline $\mathrm{BOD}_{5}$ & $\mathrm{mg} / \mathrm{L}$ & $160 \pm 14$ \\
\hline $\mathrm{TSS}$ & $\mathrm{mg} / \mathrm{L}$ & $180 \pm 17$ \\
\hline $\mathrm{pH}$ & - & $7.5 \pm 0.43$ \\
\hline $\mathrm{DO}$ & $\mathrm{mg} / \mathrm{L}$ & $3 \pm 0.2$ \\
\hline Temperature & ${ }^{\circ} \mathrm{C}$ & $22.5 \pm 3.5$
\end{tabular}

\subsection{Reactors operation}

In this study, two systems were worked 3 cycle per day. The excess sludge was drawn to sludge tank after the decant period to maintain the suspended MLSS at $2000 \mathrm{mg} / \mathrm{L}$ by using sludge pipe at the bottom of the reactor. The supernatant was discharged through fixed pipe during the drawing phase according to VER applied. In each run as shown in Table 3, each system was operated for about 1 month. All experiments were performed at the room temperature $\left(20-25^{\circ} \mathrm{C}\right)$ in a laboratory of Bilqas W.W.T.P.

Table 3

Operational program of both SBR and MSBR under different organic loading rates

\begin{tabular}{c||c||c||c||c} 
Parameters & Run 1 & Run 2 & Run 3 & Run 4 \\
\hline VER (\%) & 37.5 & 50 & 62.5 & 75 \\
\hline HRT (hrs.) & 21.33 & 16 & 12.8 & 10.67 \\
\hline $\begin{array}{c}\text { Max Working volume of } \\
\text { reactor (L) }\end{array}$ & 168 & 168 & 168 & 168 \\
\hline $\begin{array}{c}\text { Flow rate (L/cycle) } \\
\text { Organic loading rate (g } \\
\text { COD/m } \text {. }^{3} \text { d) }\end{array}$ & 63 & 84 & 105 & 126 \\
\hline $\begin{array}{c}\text { MLSS (suspended) } \\
\text { (mg/L) }\end{array}$ & 281.25 & 375 & 468.75 & 562.5 \\
\hline $\begin{array}{c}\text { Operating cycle (times } \\
\text { /day) }\end{array}$ & 3 & 2000 & 2000 & 2000 \\
\hline cycle time (h) & 8 & 8 & 3 & 3 \\
\hline Fill period (h) & 0.5 & 0.5 & 0.5 & 0.5 \\
\hline Aeration period & 6 & 6 & 6 & 6 \\
\hline Settle period (h) & 1 & 1 & 1 & 1 \\
\hline Decant period (h) & 0.5 & 0.5 & 0.5 & 0.5
\end{tabular}

\subsection{Acclimatization of sludge for SBR and MSBR systems}

Two reactors were seeded with activated sludge from the return line of the final sedimentation tank of Bilqas wastewater treatment plant. The activated sludge was mixed with the influent wastewater from outlet of grit removal tank. The operation program of the two systems was filling $(0.5 \mathrm{~h})$, aeration $(6 \mathrm{~h})$, settling $(1 \mathrm{~h})$ and decanting $(0.5 \mathrm{~h})$. The removed volume in each cycle was according to the volumetric exchange rate applied. After that, raw wastewater was added to the working volume of $168 \mathrm{~L}$ and the operation program was repeated. For each organic loading rate, the two systems were operated 3 cycles per day in fill and draw mode. A startup period of about 30 days for each organic loading to achieve the steady state conditions.

\subsection{Analytical methods}

The Chemical oxygen demand (COD), biochemical oxygen demand $\left(\mathrm{BOD}_{5}\right)$ and total suspended solids (TSS), 
mixed-liquor suspended solids (MLSS), and sludge volume index (SVI) were measured by using standard methods for the examination of water and wastewater [12]. Dissolved oxygen (DO) and $\mathrm{pH}$ measurements were monitored by a DO meter (Oxi 340i, WTW, Germany) and a pH meter (pH 340i, WTW, Germany) respectively. The attached biofilm on the media was determined in terms of biofilm mass. The biofilm mass on the media was determined after extraction from the media by a stomacher [12]. SRT (solid retention time) was calculated as the ratio of total MLSS of the system to the amount of sludge wasting per day. F/M was determined as a ratio of COD loading and the total bio-sludge of the system. Hydraulic retention time (HRT) was calculated as the ratio of cycle time to volumetric exchange rate applied.

The organic loading rate was determined by the following equation

Organic loading rate $=(\mathrm{Q} \times \mathrm{S} / \mathrm{V})$

where $Q$ was the wastewater flow per day, $S$ was the influent concentration and $\mathrm{V}$ was the working volume of the reactor.

The removal efficiency was determined by measuring $\mathrm{BOD}_{5}$, COD and TSS parameters before and after treatment. The following equation was used for calculating the removal efficiency:

Removal Efficiency $(\%)=\left(\mathrm{C}_{\mathrm{i}}-\mathrm{C}_{\mathrm{f}}\right) / \mathrm{C}_{\mathrm{i}} \times 100$

where $C_{i}$ and $C_{f}$ are the influent and effluent concentrations of the parameters, respectively.

\section{Results and Discussion}

\subsection{Start-up period behavior}

A start-up period of about 1 month was followed by one week of testing period in SBR and MSBR according to the organic loading rate applied to attain the steady state conditions which an effluent of COD and TSS was constant at a constant organic loading rate. During the start-up period, the biofilm was grown on the fiber plates in MSBR as shown in Fig.2.
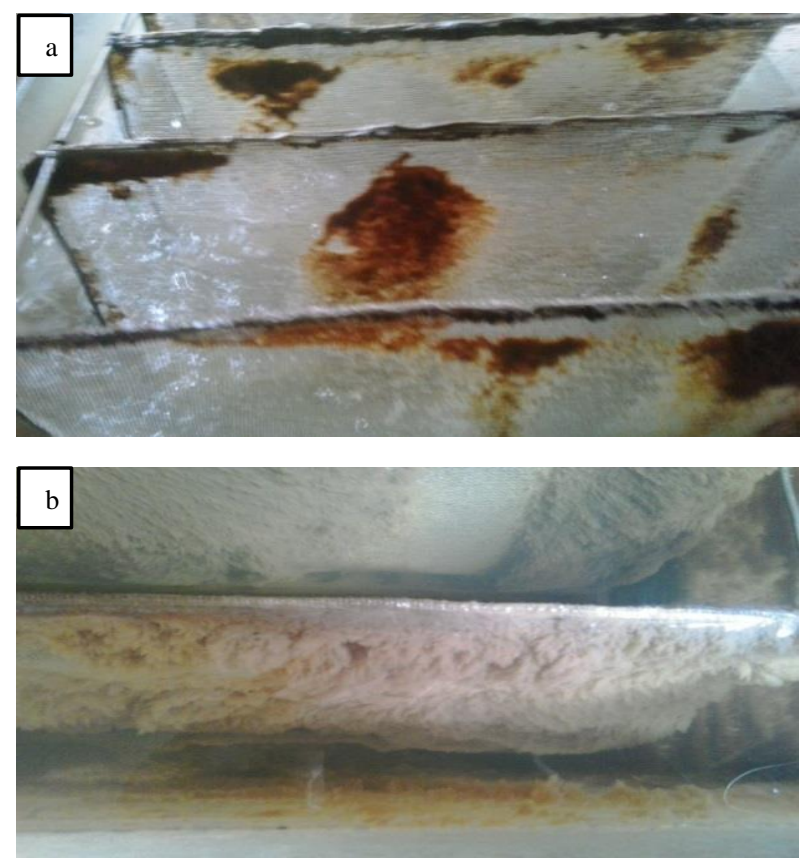

Fig.2. Shown the surface of media (a) after 5 days startup (b) after 30 days of start-up

\subsection{Effect of organic loading rates on SBR performance}

Organic loading rate (OLR) was changed by changing the volumetric exchange ratio. The OLRs corresponding to VERs of $37.5,50,62.5$ and $75 \%$ were $281.25,375,468.75$ and 562.5 $\mathrm{g} \mathrm{COD} / \mathrm{m}^{3}$. d, respectively. The SBR system under the VER of $37.5 \%$ reached steady state after 24 days of acclimatization while it was delayed to about 36 days under the VER of $75 \%$ as shown in Fig.3. The effluent COD under the highest OLR of $562.5 \mathrm{~g} \mathrm{COD} / \mathrm{m}^{3}$. d was $58 \mathrm{mg} / \mathrm{L}$ while it was $18 \mathrm{mg} / \mathrm{L}$ under the lowest OLR of $281.25 \mathrm{~g} \mathrm{COD} / \mathrm{m}^{3}$. d as shown in Fig.5. Also, the SVI increased with increasing OLR as shown in fig.6. The suspended MLSS of SBR and MSBR was controlled $2000 \mathrm{mg} / \mathrm{l}$ by wasting a certain amount of excess sludge from each reactor in each cycle. When the OLR increased from 281.25 to $562.5 \mathrm{~g} \mathrm{COD} / \mathrm{m}^{3}$. d, the $\mathrm{F} / \mathrm{M}$ ratio was increased from 0.14 to $0.28 \mathrm{~d}^{-1}$ in SBR and the sludge age went from 12.5 to 5 days as shown in Fig.6.
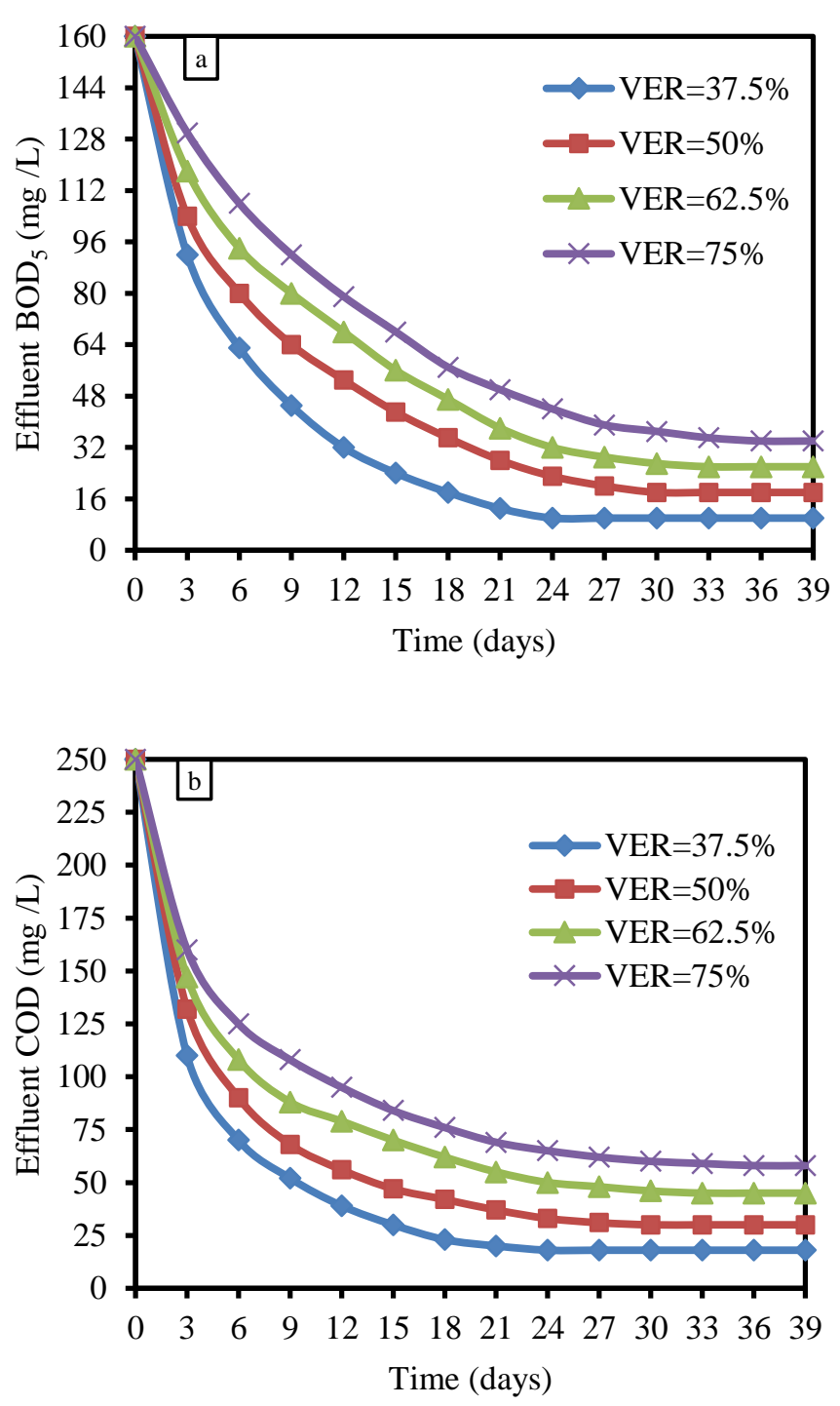


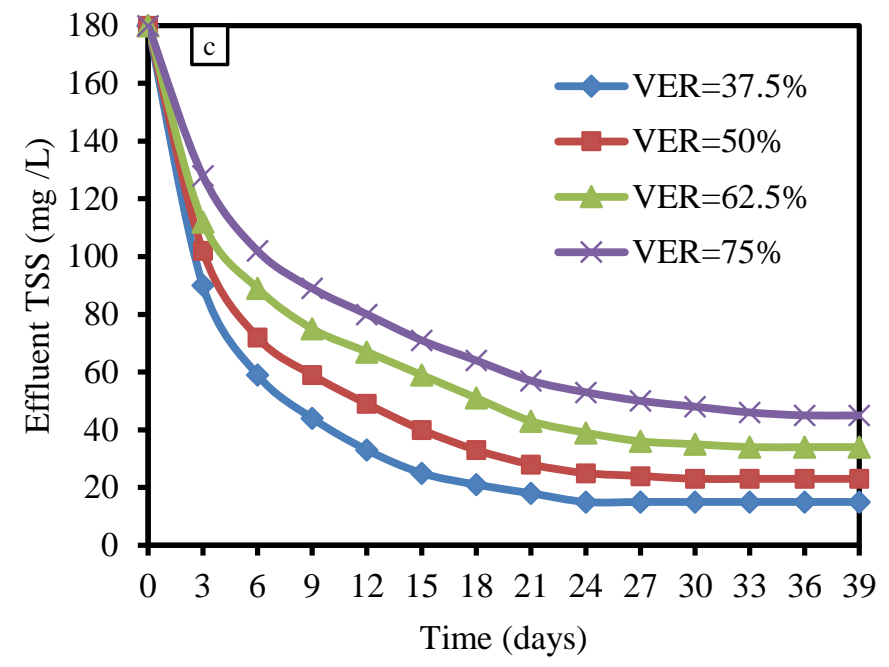

Fig.3. Effluents of $\quad$ (a) $\mathrm{BOD}_{5}, \quad$ (b) $\mathrm{COD}$ and $\quad$ (c) TSS profiles of SBR

\subsection{Effect of organic loading rates on MSBR performance}

MSBR reached steady state after 21 days of acclimatization under the VER of $37.5 \%$ while it was delayed to about 33 days under the VER of $75 \%$ as shown in Fig.4. The average effluent concentrations of COD increased from 4 to $32 \mathrm{mg} / \mathrm{L}$ when the organic loading increased from 281.25 to $562.5 \mathrm{~g} \mathrm{COD} / \mathrm{m}^{3}$. d as shown in Fig.5. The SVI under highest OLR was $98 \mathrm{ml} / \mathrm{g}$ while it was $33 \mathrm{ml} / \mathrm{g}$ under lowest OLR. When the OLR increased from 281.25 to $562.5 \mathrm{~g} \mathrm{COD} / \mathrm{m}^{3}$. d, the F/M ratio was increased from $0.15 \mathrm{~d}^{-1}$ to $0.18 \mathrm{~d}^{-1}$ and SRT of the reactor system decreased from 15 days to 7 days as shown in Fig.6. Declining in the OLR means less carbon was supplied to the microorganisms in the reactor and hence, less growth occurred.

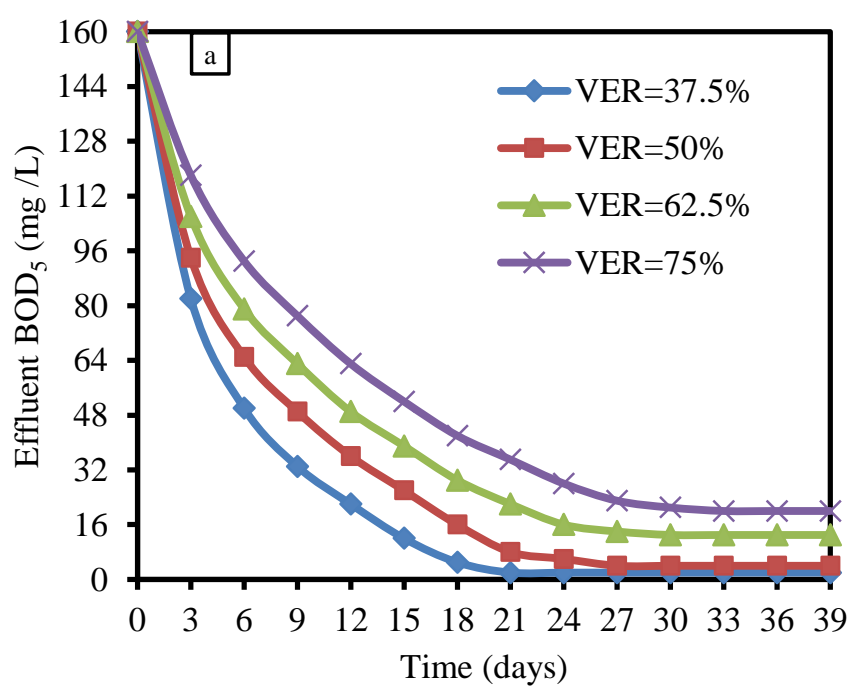

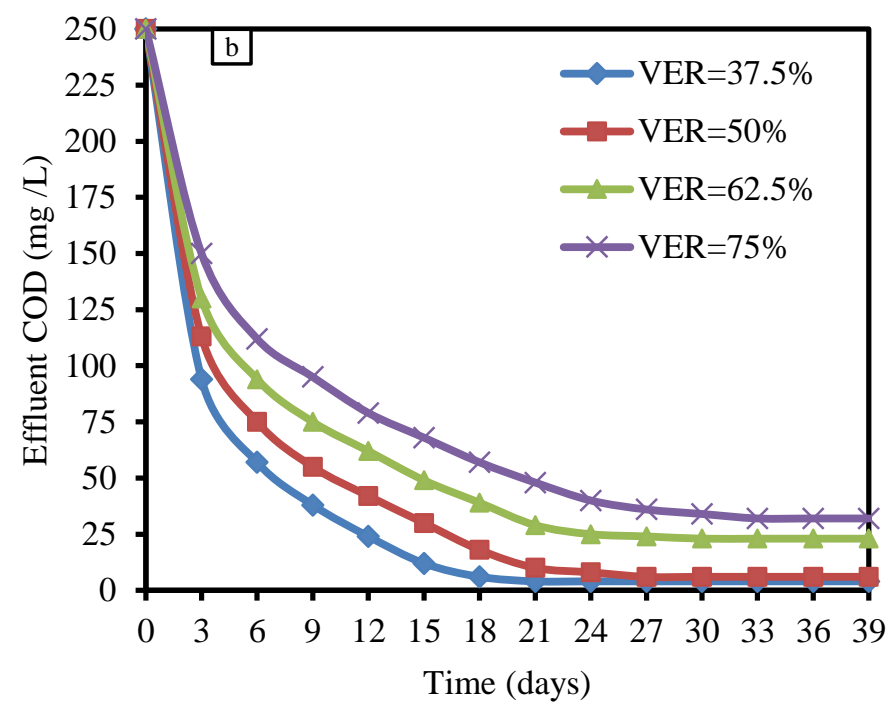

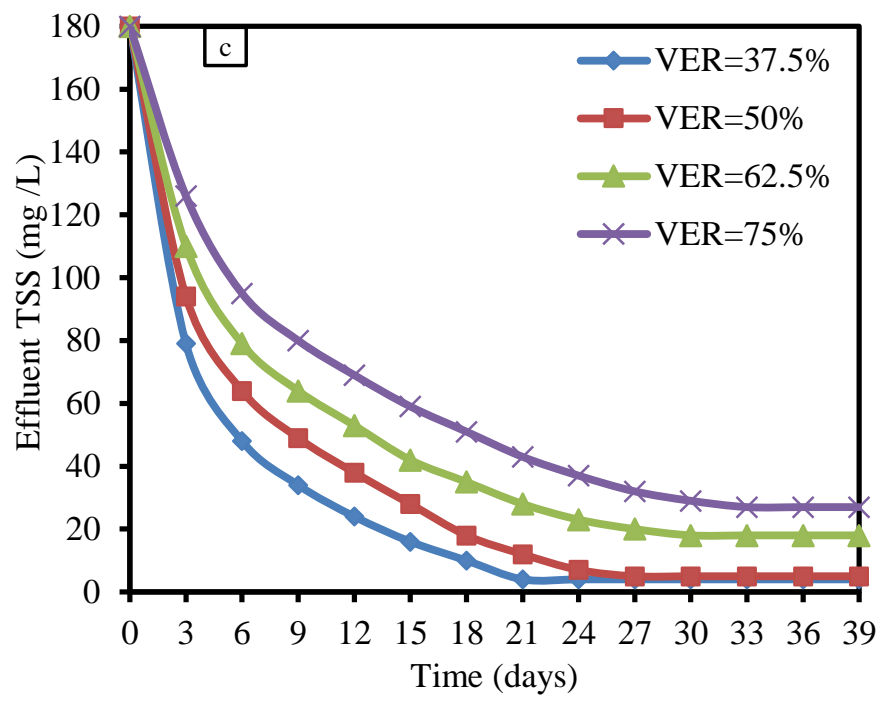

Fig.4. Effluents of (a) $\mathrm{BOD}_{5}$, (b) COD and (c) TSS profiles of MSBR

\subsection{Effect of fixed plates on COD, BOD5 and TSS effluents}

The results showed that the performance of SBR is not high because this is the traditional activated sludge wastewater system and it could not be decreasing the F/M value in the processes. Gürtekin, E.[13] investigated the effect of zeolite powder addition on the performance of SBR for the treatment of municipal wastewater under the conditions of low temperature with four cycles per day and reported that, the average COD removal efficiency in the zeolite SBR around 90\%. Husham T.Y. [14] investigated the performance of SBR for treating domestic wastewater. The SBR operated 3 cycles per day under volumetric exchange ratio of $50 \%$. One cycle consisted of $1 \mathrm{~h}$ filling, $5 \mathrm{~h}$ aeration, $1 \mathrm{~h}$ settling time and $1 \mathrm{~h}$ decanting. The results showed that the COD removal efficiency was $90.14 \%$. Debik and Manav[15] studied biological removal of nutrient from the domestic wastewater in SBR, four different cycle times were used and $8 \mathrm{~h}$ cycle time was found to be optimum and removal efficiencies of COD 
was reported to be $91 \%$. From comparison of the results of the present study with the literature, it was clear that, MSBR showed better performance compared with the conventional SBR. The removal efficiencies of MSBR was higher than conventional SBR because of the following reasons: the total bio-sludge of MSBR was more than that of conventional SBR by about $32 \%$, which resulted in the decline of $\mathrm{F} / \mathrm{M}$ of the system by about $33 \%$. The SVI of the MSBR was about $30 \%$ less than that of the SBR under the same OLR applied. The increasing in the biomass concentration was done by two factors. First, the fixed plates installed had a high specific surface area, which could provide a high surface area per unit volume of reactor. Second, the attachment of the biomass to the fixed plates through the attachment process increased the total biomass concentration in the reactor to degrade the substrate.
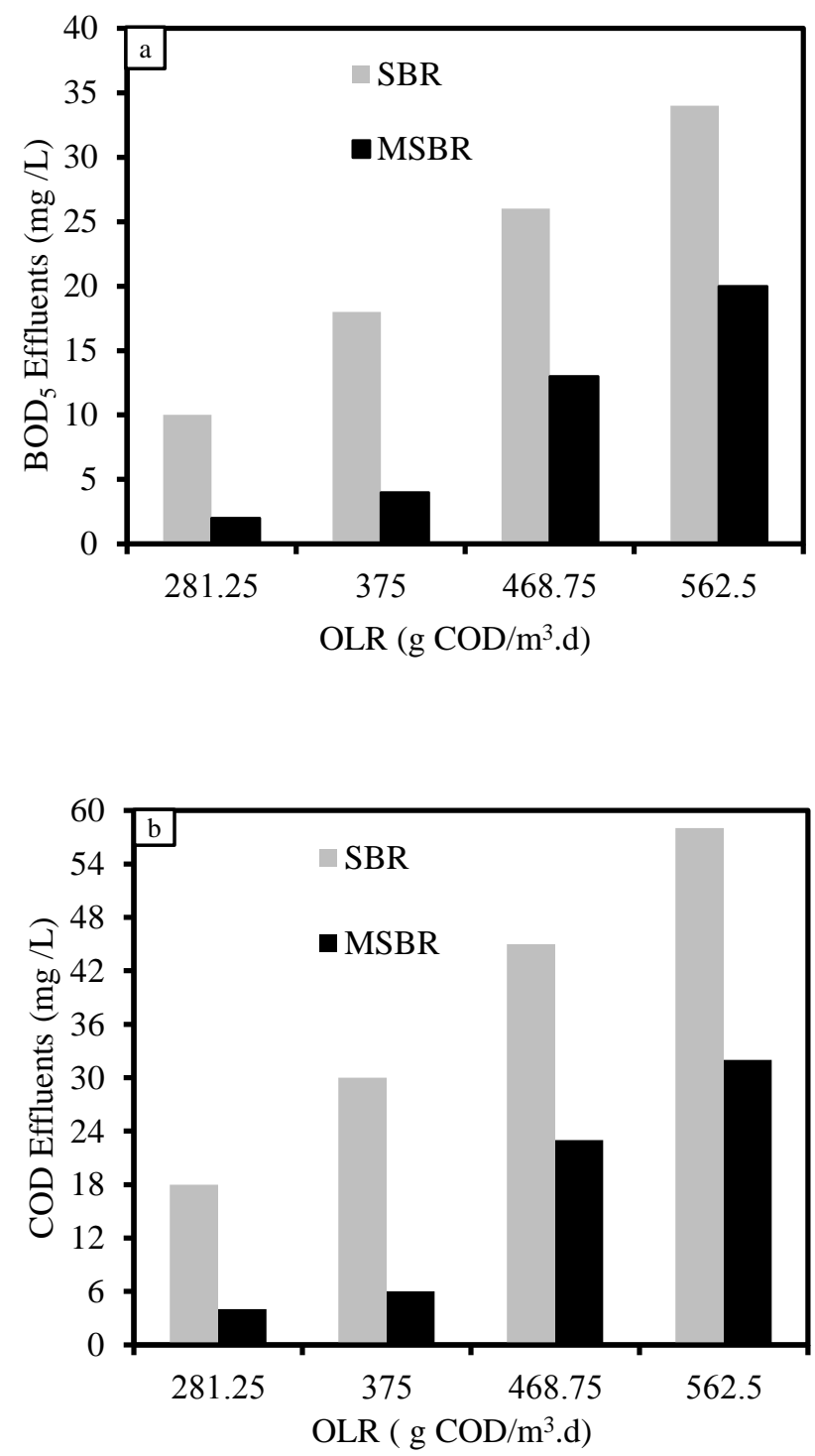

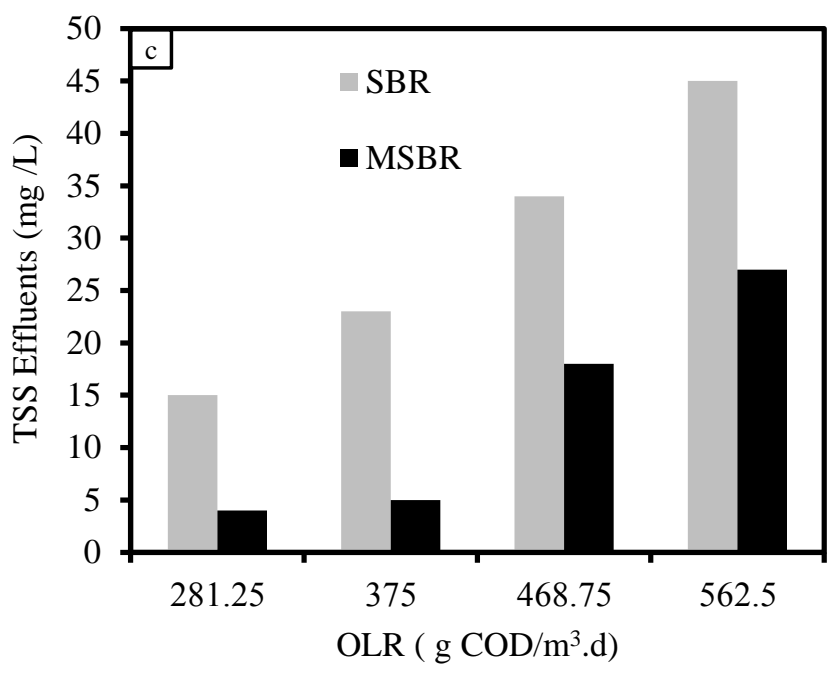

Fig.5. Effluents of (a) $\mathrm{BOD}_{5}$, (b) COD and (c) TSS profiles for SBR and MSBR at different OLRs
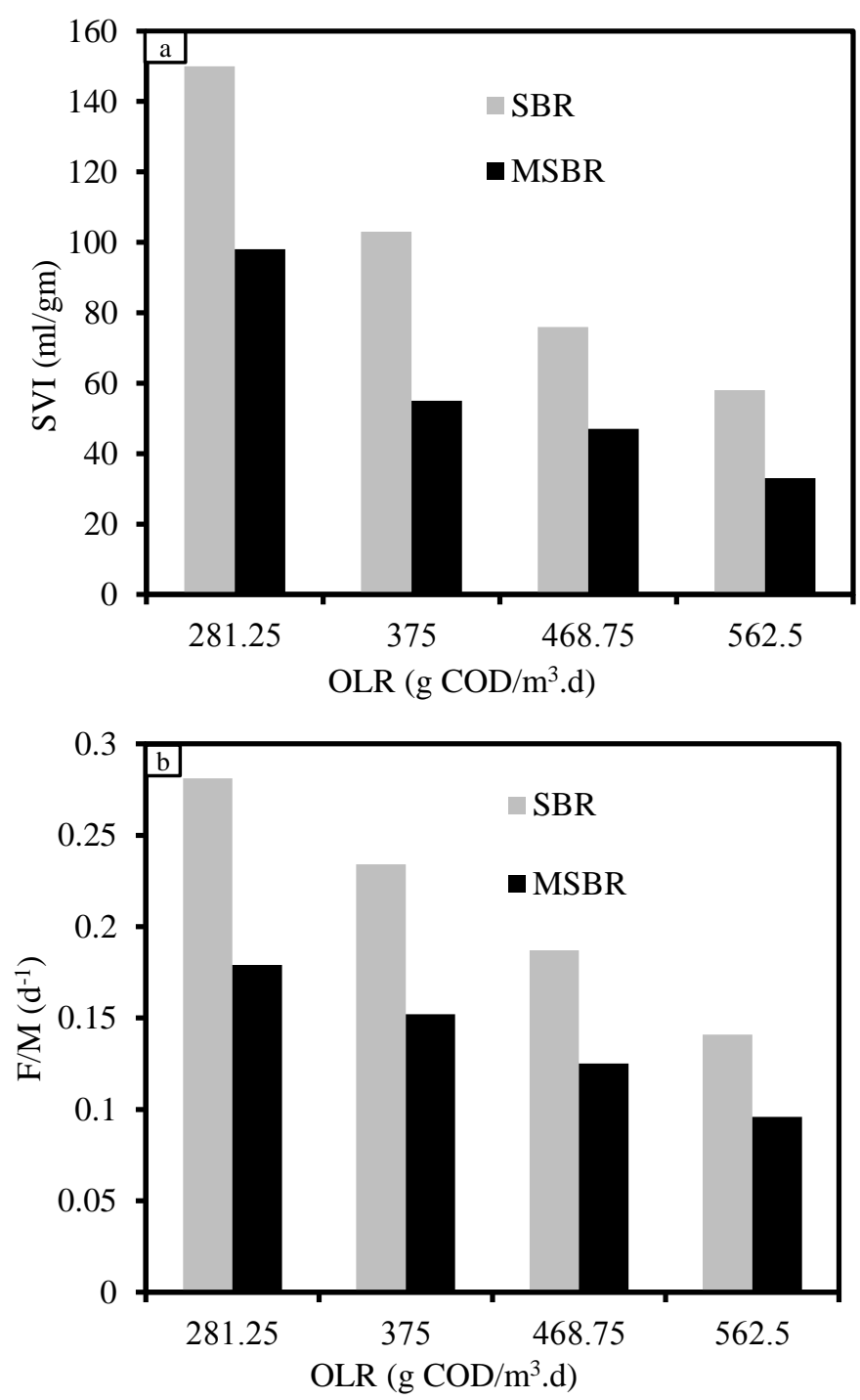


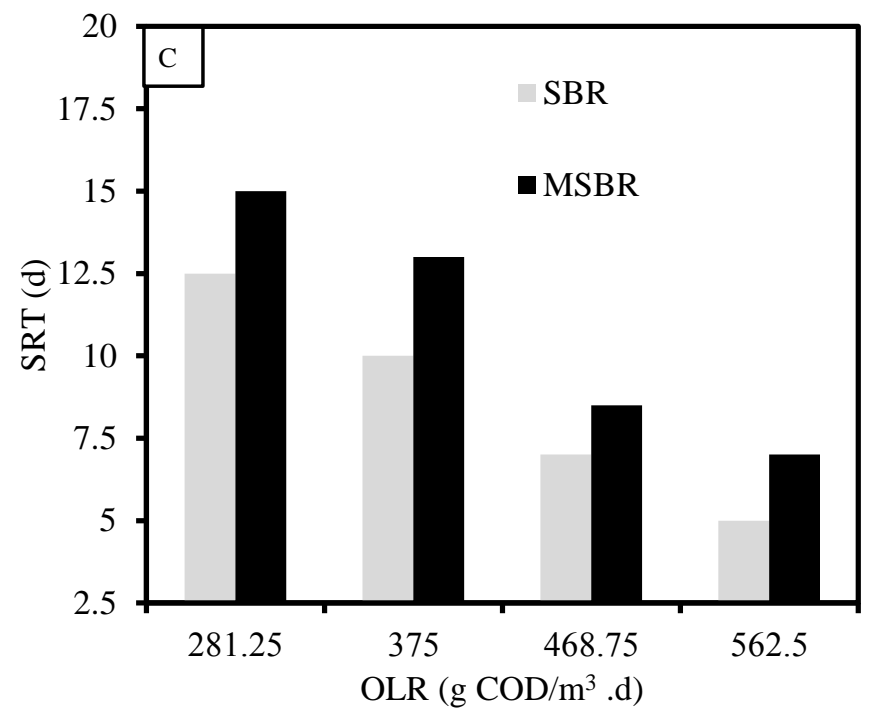

Fig.6. (a) SVI, (b) F/M and (c) SRT for SBR and MSBR at different OLRs

\section{CONCLUSION}

MSBR, which was developed for this research, achieved effective treatment of municipal wastewater. The removal efficiencies of conventional SBR and MSBR was increased by decreasing the organic loading rate (OLR). $\mathrm{BOD}_{5}, \mathrm{COD}$ and TSS removal efficiencies of MSBR was higher than the conventional SBR by $(6-12) \%$ at different OLRs. The startup period of MSBR was 3 days faster than that of SBR system. The F/M of MSBR was lower than that of SBR by about 32\%. MSBR produced less excess sludge and the quality of bio-sludge was enhanced resulting in SVI value was decreased. Overall, high performance of the investigated MSBR in the removal of pollutants could be attributed to existence of the attached biofilm on the fixed plates of a high effective surface area. Therefore, the MSBR will be preferable for use in the treatment of municipal wastewater because of high carbon removal rate and good sludge settling properties.

\section{References}

[1] T. Ertugrul, A. Berktay, and B. Nas, "Influence of salt and Cr (VI) shock loadings on oxygen utilization and COD removal in SBR," Environ. Eng. Sci., vol. 23, no. 6, pp. 1055-1064, 2006.

[2] S. Sirianuntapiboon and S. Yommee, "Application of a new type of moving bio-film in aerobic sequencing batch reactor (aerobic- SBR)," J. Environ. Manage., vol. 78, no. 2, pp. 149-156, 2006.

[3] A. Sarti, M. L. Garcia, M. Zaiat, and E. Foresti, "Domestic sewagetreatment in a pilot-scale anaerobic sequencing batch biofilm reactor (ASBBR)," Resour. Conserv. Recycl., vol. 51, no. 1, pp. 237247, 2007.

[4] M. Rodgers, D. De Paor, and E. Clifford, "Dairy washwater treatment using a horizontal flow biofilm system," J. Environ. Manage., vol. 86, no. 1, pp. 114-120, 2008.
[5] M. Rodgers, A. Lambe, and L. Xiao, "Carbon and nitrogen removal using a novel horizontal flow biofilm system," Process Biochem., vol. 41, no. 11, pp. 2270-2275, 2006.

[6] J. Prendergast, M. Rodgers, and M. G. Healy, "The efficiency of a sequencing batch biofilm reactor in organic carbon and phosphorus removal," J. Environ. Sci. Heal. Part A, vol. 40, no. 8, pp. 1619-1626, 2005.

[7] C. Lopez-Lopez et al., "Influence of filling ratio and carrier type on organic matter removal in a moving bed biofilm reactor with pretreatment of electrocoagulation in wastewater treatment," J. Environ. Sci. Heal. Part A, vol. 47, no. 12, pp. 1759-1767, 2012.

[8] M. Abdulgader, Q. J. Yu, A. Zinatizadeh, and P. Williams, "Biological treatment of milk processing wastewater in a sequencing batch flexible fibre biofilm reactor," Asia-Pacific J. Chem. Eng., vol. 4, no. 5, pp. 698703, 2009.

[9] H. A. Aziz, N. N. A. Puat, M. Y. D. Alazaiza, and Y.-T. Hung, "Poultry slaughterhouse wastewater treatment using submerged fibers in an attached growth sequential batch reactor," Int. J. Environ. Res. Public Health, vol. 15, no. 8, p. 1734, 2018.

[10] S. Sirianuntapiboon, N. Jeeyachok, and R. Larplai, "Sequencing batch reactor biofilm system for treatment of milk industry wastewater," J. Environ. Manage., vol. 76, no. 2, pp. 177-183, 2005.

[11] A. Al-sarawy, K. Al-Alfy, M. Fouad, and D. Hussein, "SLAUGHTERHOUSE WASTEWATER TREATMENT USING AEROBIC SEQUENCING BATCH BIOFILM REACTOR," vol. 43, no. 2, pp. 267-279, 2014.

[12] A. P. H. Association, A. W. W. Association, W. P. C. Federation, and W. E. Federation, Standard methods for the examination of water and wastewater, vol. 2. American Public Health Association., 2017.

[13] E. GÜRTEKIN, "Tannery Wastewater Treatment by Sequencing Batch Biofilm Reactor Tannery Wastewater Treatment by Sequencing Batch Biofilm Reactor," Techno-Science, vol. 2, no. 2, pp. 33-39, 2019.

[14] H. T. Y. Ibrahim, "Study of aeration TimeEffect on COD and Ammonia removal by sequencing batch reactor," J. Univ. Babylon, vol. 25, no. 1, pp. 276-284, 2017.

[15] E. Debik and N. Manav, "Sequence optimization in a sequencing batch reactor for biological nutrient removal from domestic wastewater," Bioprocess Biosyst. Eng., vol. 33, no. 5, pp. 533-540, 2010.

\section{Title Arabic:}

$$
\text { تأثير زيادة الحمل العضوى على أداء المفاعل التدفقى المتسلسل التقليدى }
$$

\section{Arabic Abstract:}

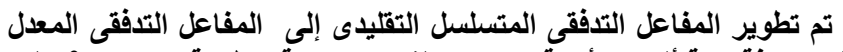

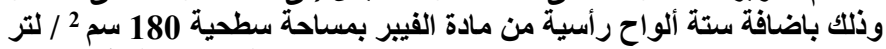

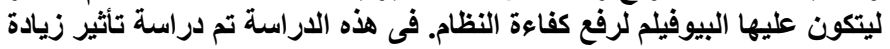

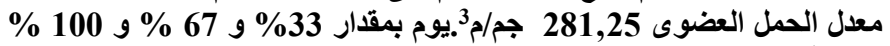

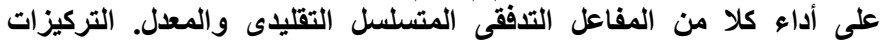

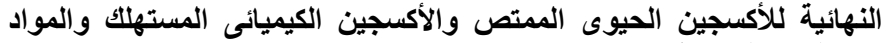

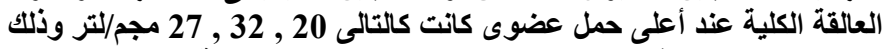

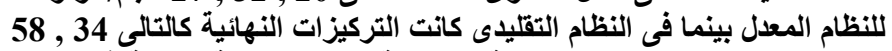

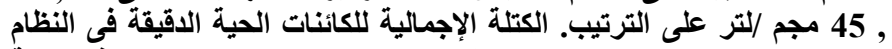

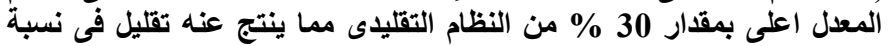

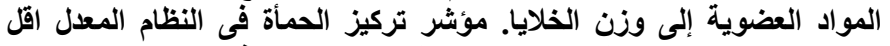
بحوالى 33 \% من النظام التقليدى. النظام المفاعل التدفقى المتسلسل فئل المعدل قادر على معالجة مياه الصرف الصحى بأداء عالي. 